\title{
Quaternary Glaciations of the Atlas Mountains, North Africa
}

DOI:

10.1016/B978-0-444-53447-7.00076-3

Link to publication record in Manchester Research Explorer

\section{Citation for published version (APA):}

Hughes, P. D., Fenton, C. R., \& Gibbard, P. L. (2011). Quaternary Glaciations of the Atlas Mountains, North Africa. In Developments in Quaternary Science/Dev. Quat. Sci. (Vol. 15, pp. 1065-1074). Elsevier BV. https://doi.org/10.1016/B978-0-444-53447-7.00076-3

\section{Published in:}

Developments in Quaternary Science|Dev. Quat. Sci.

\section{Citing this paper}

Please note that where the full-text provided on Manchester Research Explorer is the Author Accepted Manuscript or Proof version this may differ from the final Published version. If citing, it is advised that you check and use the publisher's definitive version.

\section{General rights}

Copyright and moral rights for the publications made accessible in the Research Explorer are retained by the authors and/or other copyright owners and it is a condition of accessing publications that users recognise and abide by the legal requirements associated with these rights.

\section{Takedown policy}

If you believe that this document breaches copyright please refer to the University of Manchester's Takedown Procedures [http://man.ac.uk/04Y6Bo] or contact uml.scholarlycommunications@manchester.ac.uk providing relevant details, so we can investigate your claim.

\section{OPEN ACCESS}




\section{Provided for non-commercial research and educational use only. Not for reproduction, distribution or commercial use.}

This chapter was originally published in the book Developments in Quaternary Science, Vol.15, published by Elsevier, and the attached copy is provided by Elsevier for the author's benefit and for the benefit of the author's institution, for noncommercial research and educational use including without limitation use in instruction at your institution, sending it to specific colleagues who know you, and providing a copy to your institution's administrator.

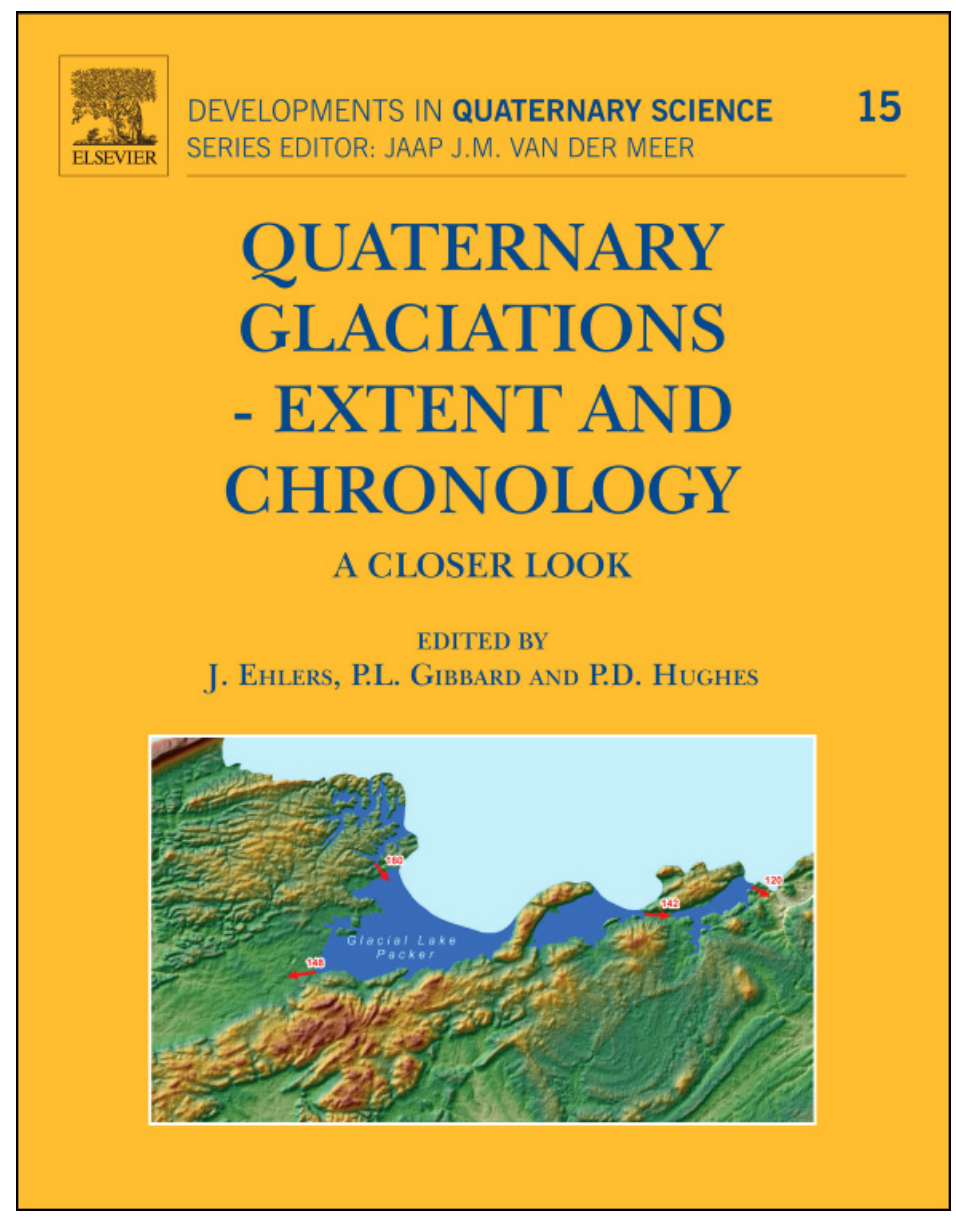

All other uses, reproduction and distribution, including without limitation commercial reprints, selling or licensing copies or access, or posting on open internet sites, your personal or institution's website or repository, are prohibited. For exceptions, permission may be sought for such use through Elsevier's permissions site at: http://www.elsevier.com/locate/permissionusematerial

From: Philip D. Hughes, C.R. Fenton and Philip L. Gibbard, Quaternary Glaciations of the Atlas Mountains, North Africa. In J. Ehlers, P.L. Gibbard and P.D. Hughes, editors: Developments in Quaternary Science, Vol. 15, Amsterdam, The Netherlands, 2011, pp. 1065-1074. ISBN: 978-0-444-53447-7.

(C) Copyright 2011 Elsevier B.V. Elsevier. 


\title{
Quaternary Glaciations of the Atlas Mountains, North Africa
}

\author{
Philip D. Hughes ${ }^{1, *}$, C.R. Fenton ${ }^{2}$ and Philip L. Gibbard ${ }^{3}$ \\ ${ }^{1}$ Quaternary and Geoarchaeology Research Group, Geography, School of Environment and Development, The University of Manchester, Manchester \\ M13 9PL, United Kingdom \\ ${ }^{2}$ NERC Cosmogenic Isotope Analysis Facility, Scottish Universities Environmental Research Centre, Scottish Enterprise Technology Park, Rankine \\ Avenue, East Kilbride, Glasgow G75 OQF, United Kingdom \\ ${ }^{3}$ Cambridge Quaternary, Department of Geography, Downing Place, University of Cambridge, Cambridge CB2 3 EN, United Kingdom \\ *Correspondence and requests for materials should be addressed to Philip D. Hughes. E-mail: philip.hughes@manchester.ac.uk
}

\subsection{INTRODUCTION}

The Atlas Mountains contain the highest mountains of North Africa and some of the highest mountains that surround the Mediterranean basin, several of which exceed $4000 \mathrm{~m}$ a.s.l. The mountains stretch over $1500 \mathrm{~km}$ from central Morocco to northern Tunisia and are commonly subdivided into the High, Middle and Saharan Atlas (Fig. 76.1). The mountain chain is situated at the AfricaEurasia plate boundary and has been uplifted and deformed together with its Palaeozoic basement, during the Mesozoic and Cenozoic. The highest peaks are formed in Palaeozoic basement granites and extrusive lavas such as basalt, andesite and rhyolite, whilst elsewhere the mountains are formed in uplifted and deformed Mesozoic carbonate rocks (Dresch, 1941; Pique, 2001; Pouclet et al., 2007). The highest peaks are situated at the south-western end of the range in the High Atlas and culminate in the Jbel Toubkal massif (4167 m a.s.1.). North of the Atlas proper are the Rif and Tell mountains which border the Mediterranean Sea and extend from northern Morocco to Tunisia. They are a folded range consisting of carbonates, flysch and crystalline basement rocks (Pique, 2001).

Glacial and periglacial activity has occurred in North and West Africa on numerous occasions. The oldest recorded is that of the Ordovician ice sheet, which existed over what was then western Gondwanaland (Ghienne, 2003). More recent, Quaternary glacial and periglacial features are in evidence throughout the Atlas Mountains (Hughes et al., 2004) like in many other mountains surrounding the Mediterranean basin (Hughes et al., 2006) and also other high mountains across Africa (Osmaston and Harrison, 2005; Mark and Osmaston, 2008). However, no modern glaciers exist although periglacial activity is thought to be still active above $2000 \mathrm{~m}$ (Couvreur, 1966; Robinson and Williams, 1992).

Climatically, the Atlas Mountains experience humid conditions in the northern section bordering the Mediterranean Sea and progressively drier conditions towards the southwest. The climate is strongly seasonal with dry summers and precipitation in winter (Delannoy, 1971). In the north, in regions bordering the Mediterranean, such as the Djurdjura massif in the Greater Kabylie area of the Algerian Tell, precipitation exceeds $2000 \mathrm{~mm}$ (Vita-Finzi, 1969, p. 54). At Ifrane, in the Middle Atlas, Morocco, mean annual precipitation (1961-1990) is also relatively high at $1118 \mathrm{~mm}$ (World Meteorological Organisation, 1998). In contrast, at Midelt, in the lee of the Middle Atlas at the foot of the northern-eastern High Atlas, the 1957-1989 annual precipitation average is just $208 \mathrm{~mm}$ (World Meteorological Organisation, 1998), although totals vary considerably year on year from $<100$ to nearly $500 \mathrm{~mm}$ (Rhanem, 2009). Precipitation values from the highest parts of the High Atlas are rare, although Messerli (1967) noted mean annual precipitation totals of ca. $800 \mathrm{~mm}$ on the north-western flanks of the Toubkal massif. The eastern flanks of the Atlas range, draining into the Sahara region, are particularly arid with annual precipitation as low as $200 \mathrm{~mm}$ in the south-east foothills of Jbel Toubkal in the High Atlas (Messerli, 1967; Rhanem, 2009).

\subsection{THE HIGH ATLAS}

The highest mountains in North Africa exist in this region, including the Jbel Toubkal (4165 $\mathrm{m}$ a.s.1.), Irhil M'Goun (4071 $\mathrm{m}$ a.s.l.) and Jbel Ayachi (3751 m a.s.l.). Glacial 


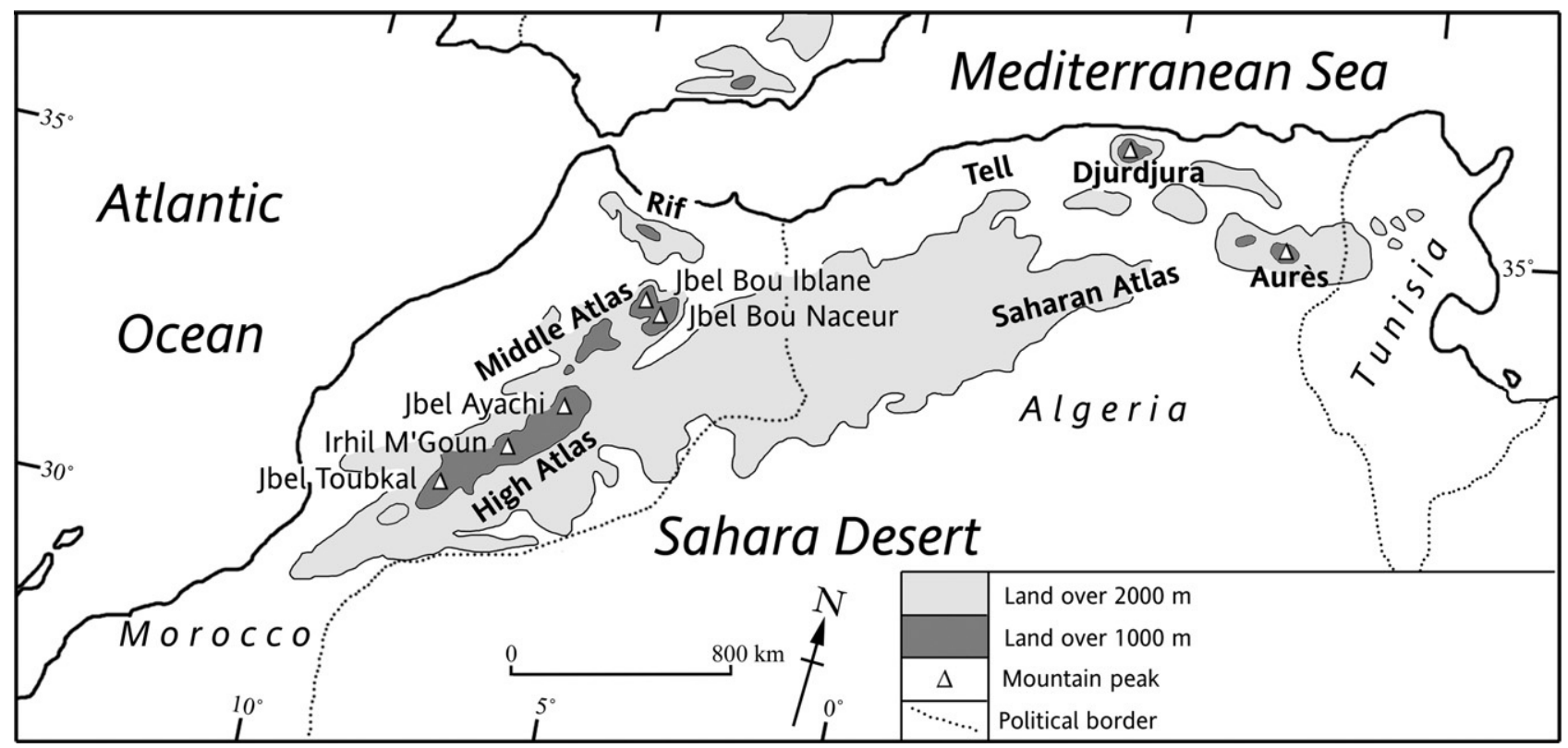

FIGURE 76.1 Location map of the Atlas Mountains indicating mountain areas mentioned in the text.

features such as cirques, troughs, roche moutonée, riegels and moraines have been noted in all these massifs (Dresch, 1941, 1949; Heybrock, 1953; Mensching, 1953; Wiche, 1953; Awad, 1963; Beaudet, 1971).

The largest glaciers formed in the Toubkal massif, where valley glaciers emanated from a central ice field which formed between the two highest summits, Toubkal (4167 $\mathrm{m}$ a.s.1.) and Ouanuokrim (4067 $\mathrm{m}$ a.s.1.). The northern outlet glacier draining this ice field extended nearly $10 \mathrm{~km}$ to an altitude of just $2000 \mathrm{~m}$ a.s.1., ca. $1 \mathrm{~km}$ downvalley of the shrine of Sidi Chamarouch. Valley glaciers also formed on the northern slopes of Aksoual and Bou Iguenouane. Well-defined cirques are present in the upper catchments around Toubkal and on the northern slopes of Aksoual and Bou Iguenouane and these cirques contain moraines (Figs. 76.2 and 76.3). In fact, at least three separate moraine units are present in these mountains, widely separated in altitude with some moraines present at elevations as low as $2000 \mathrm{~m}$ a.s.l. (Fig. 76.4).

Dresch (1941) estimated that the Pleistocene snowline was situated at 3600-3800 m a.s.1., whilst later workers have derived slightly lower estimates at 3400-3500 m a.s.l. (Mensching, 1953) and at 3300-3400 $\mathrm{m}$ a.s.l. (Awad, 1963). However, most researchers have underestimated the extent of glaciation in the Toubkal area and overestimated the altitude of Pleistocene snowlines. Dresch (1941) and Mensching (1953) both recognised clear moraines in the higher valleys but underestimated the extent of glaciation in some valleys where snowlines are as low as $3000 \mathrm{~m}$ a.s.l. and sometimes lower. In addition, some features have been misidentified. For example, Dresch (1941) interpreted large accumulations of boulder debris in some glaciated valleys as rock glaciers, whereas these features better resemble landslides as a result of rock-slope failure. Nevertheless, these coarse boulder deposits, like at Arroumd (also spelt Aremd or Aremdt), are closely associated with glaciation since rockslope failures and resultant landslides are common in the Mediterranean mountains and frequently occur in overdeepened glacial valleys (Figs. 76.5 and 76.6). Furthermore, it is possible that rock-slope failures produced a catastrophic landslide onto the surface of a retreating glacier in this valley. This is supported by the presence of lateral moraines bounding rock-slope-failure debris on both sides of the valley (Fig. 76.6). Cosmogenic nuclide exposure ages from boulders on both the surfaces of the landslide debris and the lateral moraines will help test this scenario further. A similar mechanism of paraglacial glacier-landslide interaction has been suggested for the formation of the barrage at Lac D'Ifni on the southern slopes of Toubkal (Celerier and Charton, 1923).

Until recently, the age of the High Atlas moraines was a matter of speculation. However, a programme of cosmogenic isotope analyses is now underway at the UK Natural Environment Research Council Cosmogenic Isotope Analysis Facility, at East Kilbride in Scotland. This dating programme is focusing on dating glacial landforms in the Toubkal massif and is applying ${ }^{10} \mathrm{Be}$ analyses to quartz veins and ${ }^{36} \mathrm{Cl}$ analyses to andesite boulders to provide estimates of exposure history for the moraines in this area. Preliminary ages are calculated using the Dunai (2001) scaling scheme in the CRONUS-Earth online calculator (Balco et al., 2008; wrapper script version 2.2, main calculator 2.1, constants 2.2.1 and muons 1.1). Three ${ }^{10} \mathrm{Be}$ ages from boulders on the highest and stratigraphically youngest 


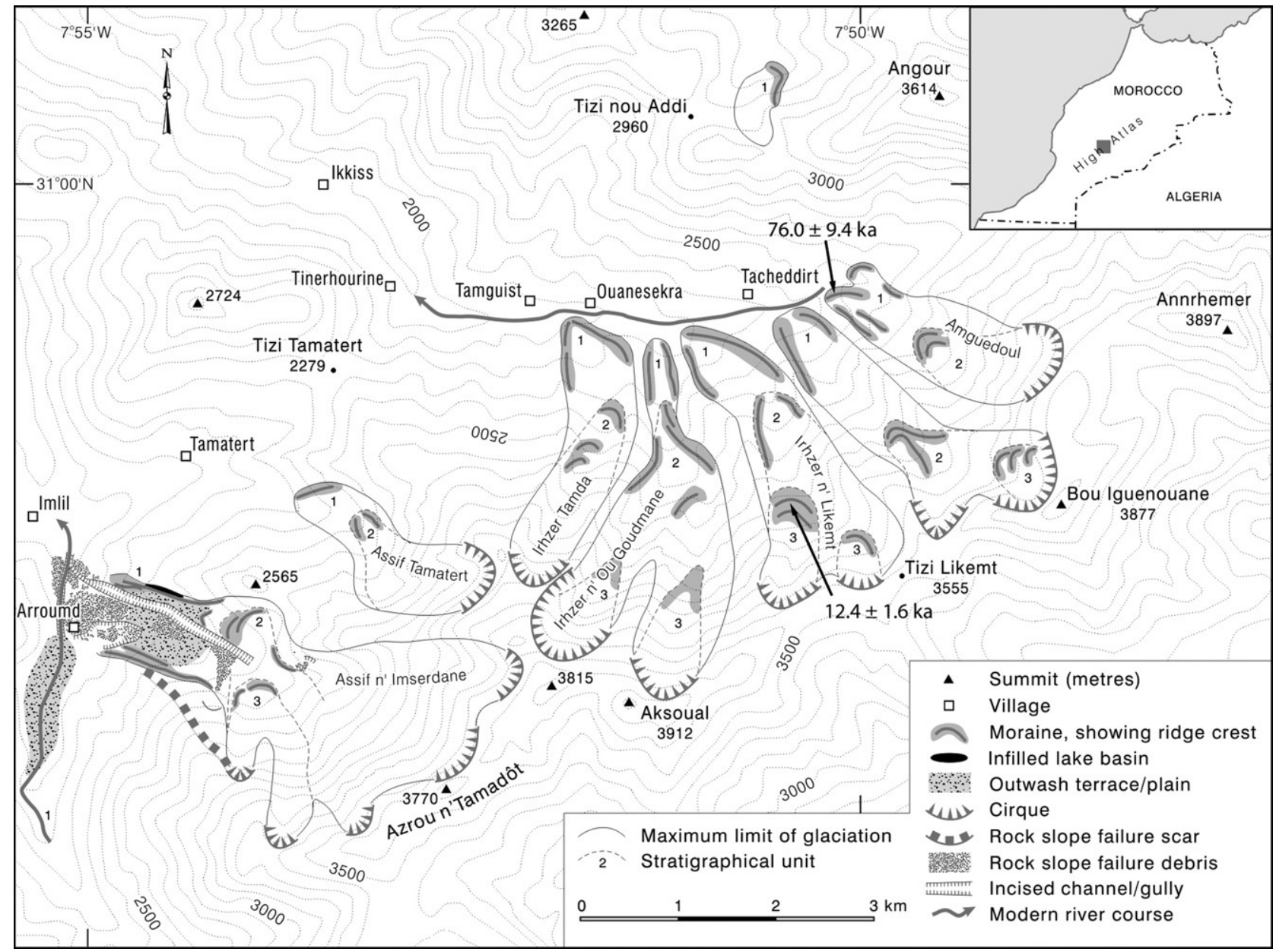

FIGURE 76.2 Glacial geomorphological map of the northern slopes of Aksoual (3912 m a.s.l.), High Atlas, Morocco, with ${ }^{10} \mathrm{Be}$ ages indicated.

FIGURE 76.3 Cirque moraines (Units 2 and 3) on the northern slopes of Bou Iguenouane (3877 m a.s.l.) in the High Atlas, Morocco (see Fig. 76.2 for location).

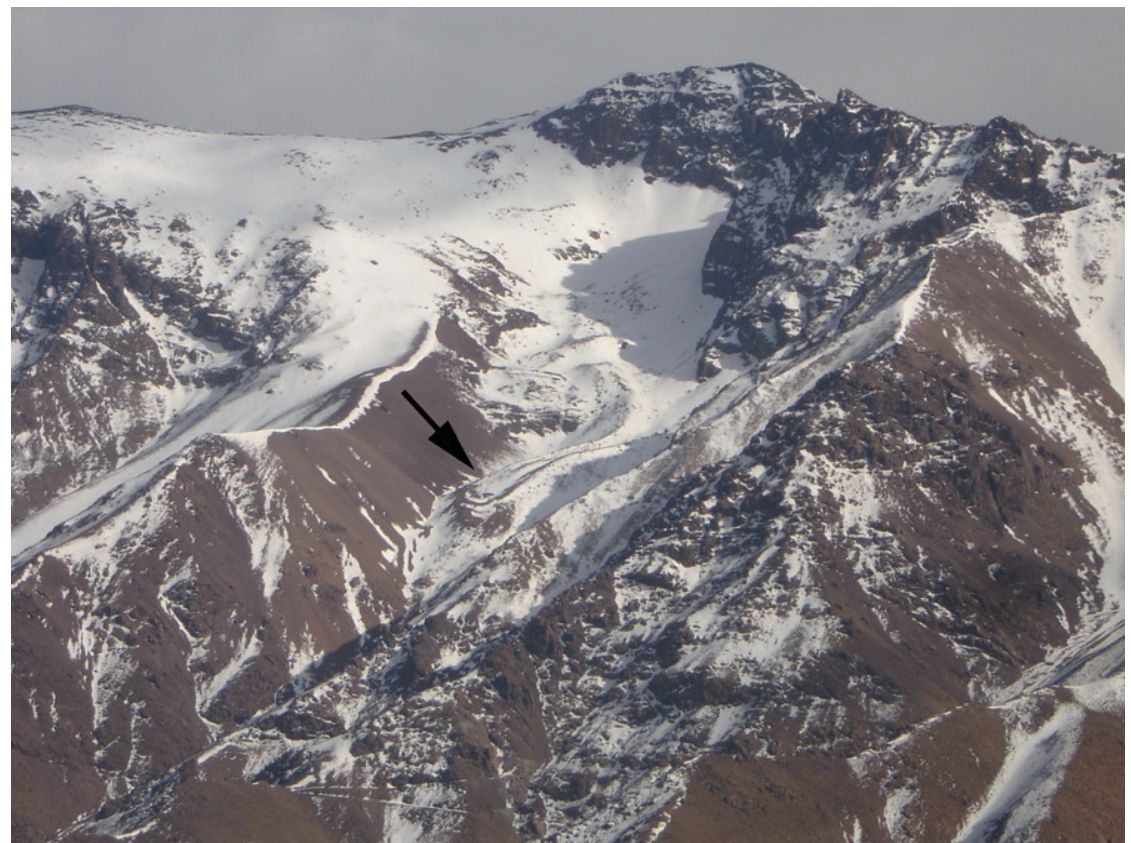




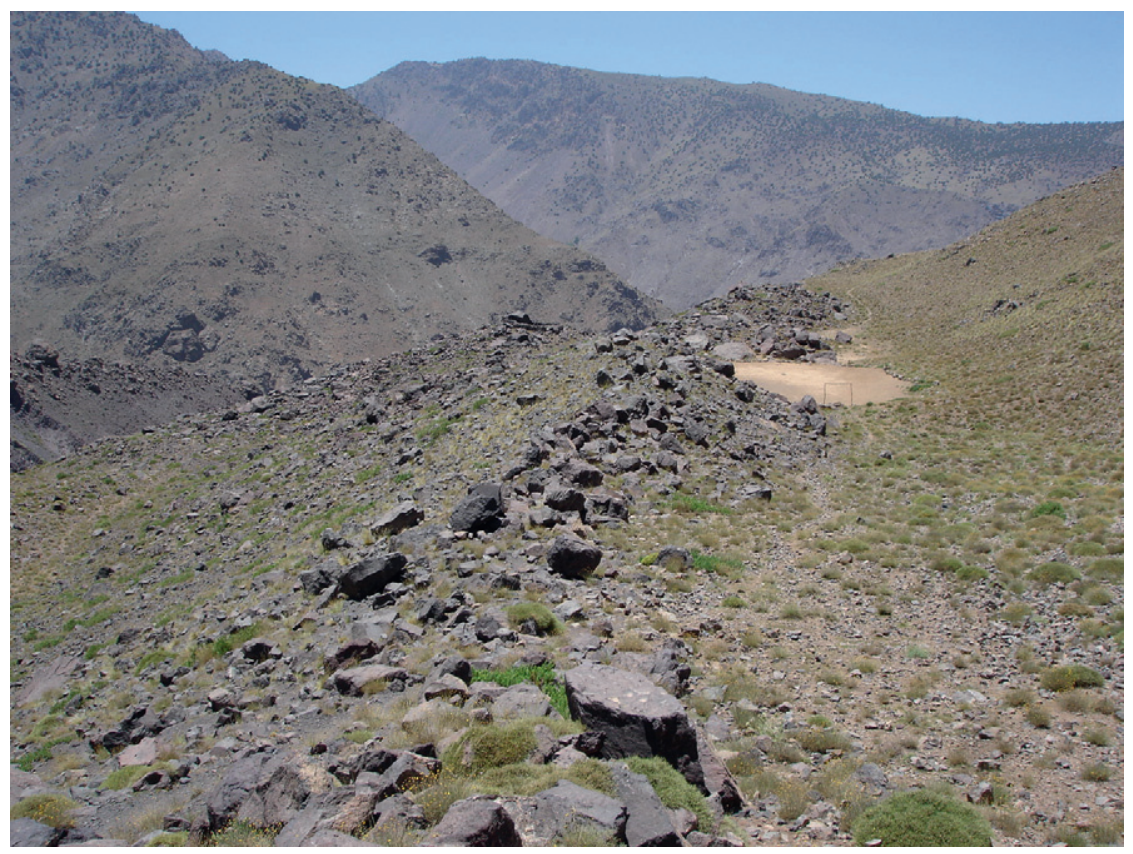

FIGURE 76.4 Lateral moraines at ca. 2000$2200 \mathrm{~m}$ a.s.l. on the northern slopes of Aksoual. The flat light-coloured area to the right of the moraine crest is an infilled basin containing several metres accumulation of lake sediments.

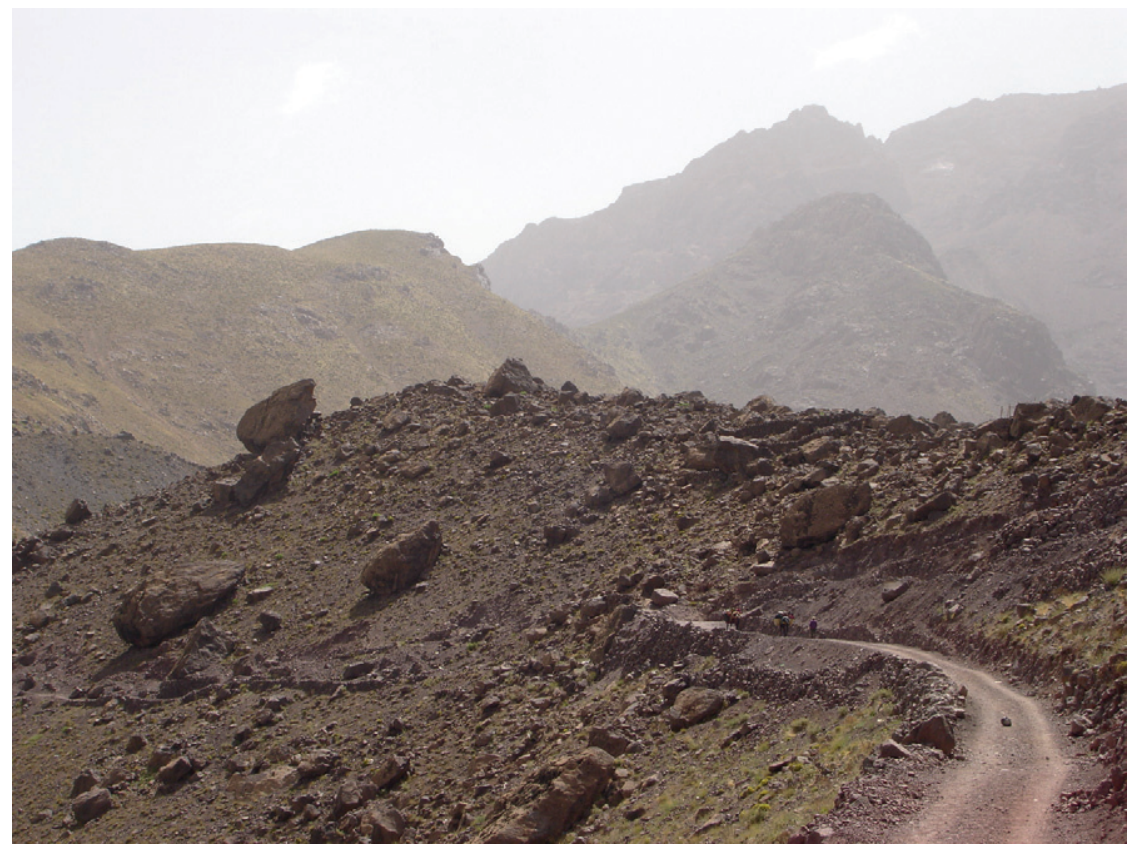

FIGURE 76.5 Landslide deposits resulting from a rock-slope failure in a glaciated valley near Arroumd in the High Atlas (see Fig. 76.2 and 76.6 for location).

moraines in the Azib Mzik and Irhzer Likemt valleys (Figs. 76.2 and 76.7; glacial unit 3; 12.4 $\pm 1.6,12.2 \pm 1.5$ and $11.1 \pm 1.4 \mathrm{ka})$ suggest that glaciers formed moraines in the High Atlas during the African Humid Period (14.8$5.5 \mathrm{ka}$ ). Interestingly, these preliminary ages fall within, or overlap within error, the Younger Dryas (12.9$11.7 \mathrm{ka}$ - - a well-known cold reversal in the North Atlantic. It must be noted that despite being the highest moraines in the Azib Mzik valley, the moraines are very low (ca. 2000$2100 \mathrm{~m}$ a.s.l.) compared with the peak altitudes in this area, and lower than the equivalent moraines in the Irhzer Likemt (2900-3000 m a.s.1.). This may be because of strong local topoclimatic controls on glacier development at this particular site. Nevertheless, it does raise the question: 'how large were equivalent glaciers elsewhere in the nearby mountains and did Holocene glaciers survive in the highest cirques?' Another ${ }^{10} \mathrm{Be}$ age, this time from the lowest and stratigraphically oldest moraines (Fig. 76.2; glacial unit 1), yielded an age of $76.0 \pm 9.4 \mathrm{ka}$ (uncorrected for erosion). Finally, a ${ }^{10} \mathrm{Be}$ age from an intermediate moraine ridge, between the 


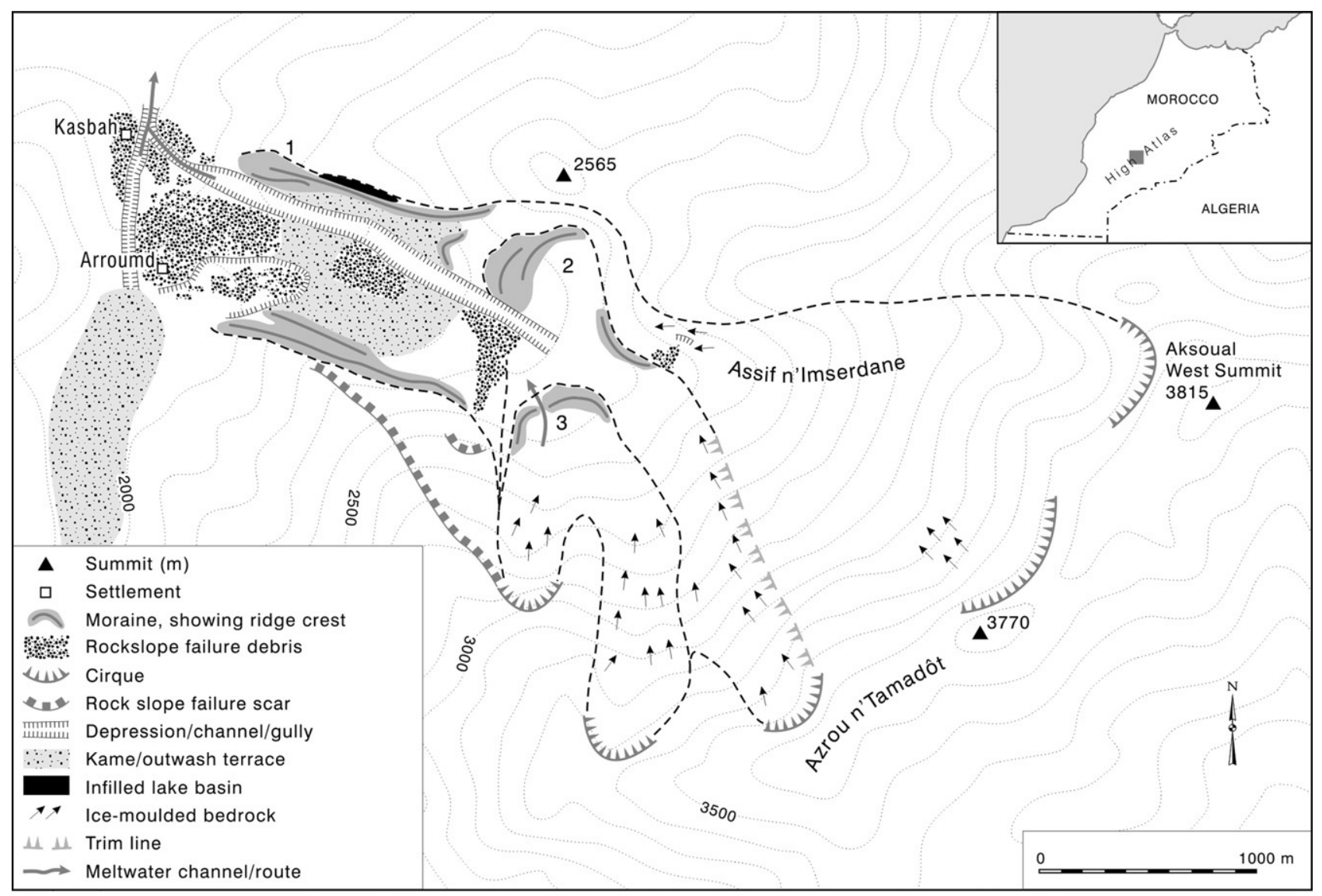

FIGURE 76.6 Geomorphological map of the Arroumd valley (Assif n'Imserdane) showing the relationship between glacial sediment units (numbered $1-3)$ and rock-slope-failure deposits.

lowest and the highest moraines in the Azib Mzik valley, yielded an exposure age of $24.4 \pm 3.0 \mathrm{ka}$ (Fig. 76.7). These preliminary results demonstrate that there is a large difference in exposure history between the oldest and youngest moraines in the High Atlas. The preliminary evidence of separate stratigraphical units yielding exposure ages of ca. 76, 24 and 12 ka suggest evidence for at least three glacial events widely separated in time. However, additional dating is needed to be confident of the timings of glaciations, and eventually, this will provide a platform from which to better understand the relationship between glacier expansions and the climatic state of the Sahara.

Several hundred kilometres north-east of the Toubkal massif, the glacial features of the Irhil M'Goun and Jbel Ayachi area were recorded by Wiche (1953) and Awad (1963). Wiche (1953) mapped the cirques and associated moraines on the northern slopes of both the highest peak of Irhil M'Goun (4070 m a.s.l.) and on nearby Jbel Ouaougoulzat (3770 m a.s.l.). On Jbel Ayachi too, cirques are well developed (Awad, 1963), although no detailed glacial geomorphological mapping has been done in this area.

Periglacial features are widespread in the High Atlas, and features such as solifluction lobes, rasentrappen, thufurs, polygons, stone stripes and felsenmeer are active today above ca. $2000 \mathrm{~m}$ a.s.l. (Couvreur, 1966). Frosts are frequent, even in modern times, where in winter, minimum temperatures at $2000 \mathrm{~m}$ a.s.l. are often in the range 0 to $-10^{\circ} \mathrm{C}$ and can fall to $-20^{\circ} \mathrm{C}$ (Robinson and Williams, 1992). Blockfields are widespread on Jbel Toubkal, and frost-shattered bedrock forms extensive talus slopes which supply the lower valleys with huge amounts of debris. For example, the valley containing Lac D'Infi (2312 m a.s.l.), to the east of Toub$\mathrm{kal}$, is choked with thick accumulations of debris. On Toubkal, Chardon and Riser (1981) reported an active rock glacier in the western cirque above the Toubkal (formerly Neltner) refuge. However, the feature could equally be interpreted as a rock-slope-failure deposit, and similar features occur at a very wide range of altitudes on Toubkal. Relict rock glaciers have been reported elsewhere in the High Atlas, such as on Irhil M'Goun and Jbel Ouaougoulzat (Wiche, 1953) and at Arroumd and several other sites near Toubkal (Dresch, 1941). However, in the Toubkal area at least, many of these 'rock glaciers' may in fact be better interpreted as landslides resulting from rockslope failures-possibly in association with glacier retreat (Celerier and Charton, 1923). 


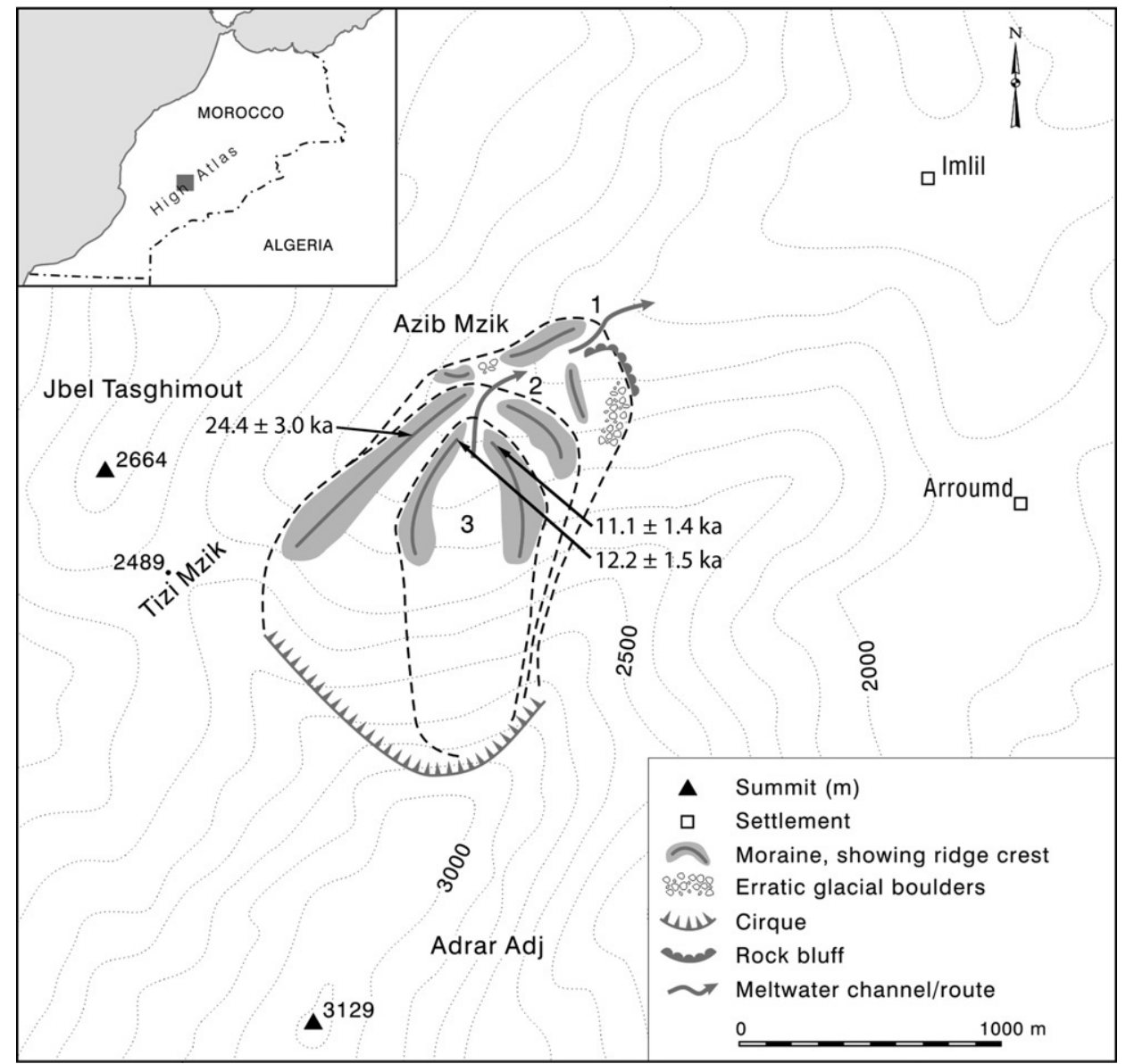

FIGURE 76.7 Glacial geomorphological map of the Azib Mzik area on the northern slopes of Adrar Adj (3129 m a.s.1.) with ${ }^{10}$ Be ages indicated.

Even today, in some sheltered cirques on Toubkal, snow fields are perennial, although the true snowline lies slightly above the highest peaks, probably at ca. $4200 \mathrm{~m}$ a.s.l. (Messerli, 1967). A notable snowfield exists below the northern cliffs of the Tazaghart plateau. This feature was mapped as 'névé permanent' on French maps dating from the 1940s and a large snowfield was observed in July 2008 , although whether it is still truly perennial is unclear. The size and nature of this feature in recent centuries is also unclear and it would not be implausible to hypothesise the presence of small niche glaciers at this site and others around the High Atlas during the 'Little Ice Age', as has been found in other mountains around the Mediterranean basin (e.g. González Trueba et al., 2008; Hughes, 2010).

\subsection{THE MIDDLE ATLAS AND THE RIF}

The Middle Atlas lies to the north-east of the High Atlas in central Morocco. Here, the highest peaks include Jbel Bou Iblane (3340 m a.s.1.) and Jbel Bou Naceur (3310 m a.s.1.), both of which show evidence of former glaciation (Dresch and Raynal, 1953; Raynal et al., 1956; Awad, 1963;
Beaudet, 1971). Periglacial features are also widely observed in the Middle Atlas as in the High Atlas further south. Stone polygons, solifluction features and rock glaciers are described on Bou Iblane and Jbel Bou Naceur by numerous workers (Raynal, 1952; Dresch and Raynal, 1953; Awad, 1963). Further details on the extensive work of René Raynal in this region can be found in Joly (2002).

The former regional snowline in the Middle Atlas is estimated to have been at ca. $2800 \mathrm{~m}$ a.s.l. during the most extensive glacial phase (Awad, 1963). According to Awad (1963), the most remarkable collection of glacial troughs in the Atlas Mountains is to be found on the southern and eastern slopes of Jbel Bou Iblane. Terminal and lateral moraines are widely preserved and extend down to ca. $2400-2500 \mathrm{~m}$ a.s.l. (Raynal et al., 1956). Awad (1963) also stated that rock glaciers are especially abundant between 2100 and $2500 \mathrm{~m}$ in the eastern valleys of the Bou Naceur massif, although, given the doubtful interpretations of rock glaciers made in earlier literature by other workers in the High Atlas, caution must be given to these claims until further research has been undertaken. Further north, the Rif mountains are thought to have lain beneath the regional snowline, 
although, according to Mensching (1960), there is evidence for former perennial snow patches and, again, rock glaciers on the highest mountain Tidirhin-Kette (2456 m a.s.l.).

\subsection{ALGERIAN ATLAS}

Glacial and periglacial features have been noted in the Djurdjura massif of the Algerian Tell (Barbier and Cailleux, 1950; Büdel. 1952; Tihay, 1972; Tihay, 1973) and in the Aurès massif of the Saharan Atlas (Ballais, 1983). In the Djurdjura massif ( $2308 \mathrm{~m}$ ), to the north-west, cirques, U-shaped valleys and terminal moraines are all in evidence, according to Barbier and Cailleux (1950). Glacial deposits extend to exceptionally low altitudes for this latitude, reaching as low as $750 \mathrm{~m}$ a.s.l. on the northern slopes and $1270 \mathrm{~m}$ a.s.l. on the west. The formation of glaciers was probably aided by snow accumulation in dolines-a topographical situation also identified as important for former glaciation elsewhere in the Mediterranean (Hughes et al., 2007), and even today, snow lies in such dolines throughout the summer above $2000 \mathrm{~m}$ a.s.l. This probably arises from high precipitation of this area, which exceeds $1500 \mathrm{~mm}$, of which most falls during the winter months. The Pleistocene snowline here, during the most extensive glacial phase, was as low as $1900 \mathrm{~m}$ a.s.l., although Büdel (1952) puts the snowline slightly higher at $2100 \mathrm{~m}$ a.s.l. As is the case today, this probably results from the influence of maritime air masses from the nearby western Mediterranean.

South-east of the Djurdjura massif, in the Aurès massif of the Saharan Atlas, Ballais (1983) noted the presence of moraines on Jbel Ahmar Khaddou (2017 m a.s.l.) and Jbel Mahmel (2321 m) above $1600 \mathrm{~m}$ a.s.l. However, none were noted on the highest peak, Jbel Chélia (2326 m a.s.l.). On the Jbel Mahmel, two phases of glaciation are evident. It would appear that conditions in this region were marginal to glaciation and glaciers only formed in exceptional topographic localities. This is no doubt due to the proximity of the arid Sahara region and low precipitation levels compared with the Djurdjura massif.

There has been very little glacial research in Algeria since the early 1980s. The extent and characteristics of the former glaciers remain very unclear. In fact, the same is true for the Middle Atlas and the Rif as well as large areas of the High Atlas, with the exception of the Toubkal massif-although even here there are still a lot of unanswered questions as to the extent and timing of past glaciations.

\subsection{PALAEOGLACIERS IN NORTH AFRICA: THEIR IMPORTANCE FOR UNDERSTANDING PALAEOCLIMATES}

The former glaciers of the Atlas Mountains in North Africa are strategically positioned for understanding Pleistocene cold-stage atmospheric circulation between the North Atlantic and the Mediterranean Sea. However, former glaciers in the Atlas Mountains have the added advantage of being in close proximity to the largest desert on earththe Sahara. The nature of the Sahara Desert in the past, especially during Pleistocene cold stages, has been the subject of debate. Traditionally, cold stages were considered to have been drier than interglacials as a result of a cooler global atmosphere with lower moisture capacity and a large amount of the Earth's hydrological budget being locked up in large ice sheets (Flint, 1971). Thus, deserts such as the Sahara were considered to have expanded during cold stages and retracted during interglacials. However, 'to equate glaciations with aridity and interglacials with an increase in desert rainfall is to oversimplify' (Williams et al., 1998). Indeed, there is widespread evidence that the end of the last cold stage over the Sahara region was characterised by a much wetter climate than present, during a time known as the African Humid Period (14.8-5.5 ka). For much of this interval, the Sahara was almost entirely covered by vegetation, whilst the mid and late Holocene saw major desert expansion and associated dust flux over the Saharan region. In fact, moisture supply to the Sahara region has fluctuated throughout the Pleistocene, and DeMenocal (2008) indentified several 'wet' phases during the last glacial cycle.

Important palaeoclimatic questions remain unanswered regarding the sources of moisture supply during glaciations. For example, did Atlantic depressions deliver moisture equitably between latitudes $30^{\circ} \mathrm{N}$ and $45^{\circ} \mathrm{N}$ during coldstage glaciations, or were there major latitudinal differences? The position of the Polar Front during cold stages at the latitude of southern Portugal (Ruddimann and McIntyre, 1981) may suggest that cyclogenesis occurred at this latitude. If so, then one might expect Atlantic depressions to track through the Straits of Gibraltar delivering moisture to both North Africa and Iberia (cf. Florineth and Schlüchter, 2000; Fig. 76.8). In the Alboran Sea, just east of the Straits of Gibraltar, Cacho et al. (1999) have shown that north-westerly winds were dominant and strengthened during stadials associated with Heinrich Events in the North Atlantic within the last cold stage and it is possible that this reflects a southerly shift in the track of depressions at these times. The extent to which Atlantic depressions penetrated North Africa may be reflected by a marked increase in glacier snowlines between the Middle and High Atlas, for example. Alternatively, there may be no differences in snowlines at particular times, and if so, this may suggest that spatial variations in glacier snowlines were controlled by precipitation rather than summer temperatures.

Another major question is "what were the relative roles of Atlantic depressions and the West African Monsoon in delivering moisture to the Atlas Mountains (and perhaps southern Iberia)?' Various hypotheses have been put 


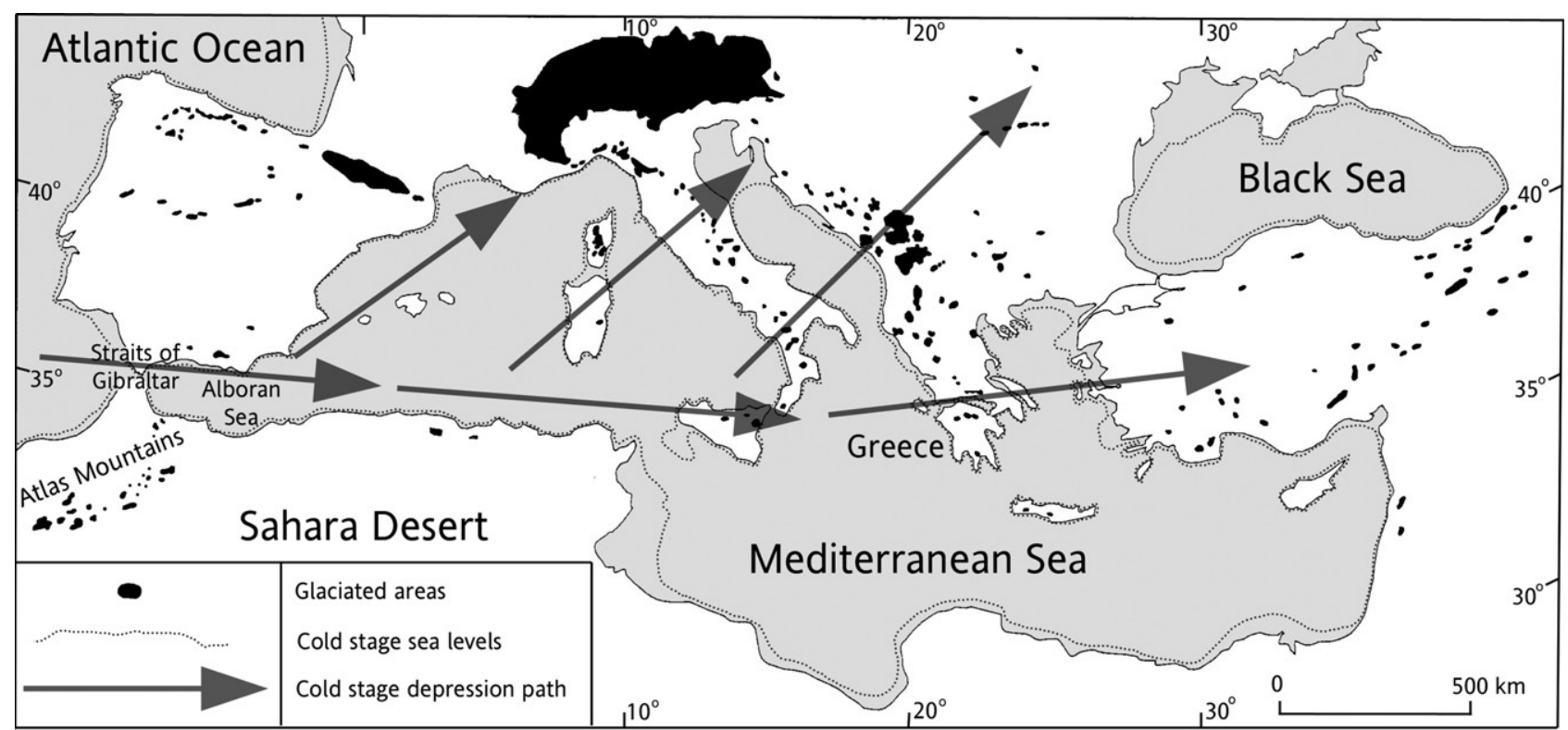

FIGURE 76.8 Distribution of Pleistocene glaciation around the Mediterranean basin and the postulated track of depressions during Pleistocene cold stages (Florineth and Schlüchter, 2000).

forward to explain the African humid periods. One hypothesis is that the West African Monsoon was strengthened when sea-surface temperatures in the North Atlantic were much cooler than present, such as during the Late Pleistocene/Early Holocene transition when the vast Laurentide ice sheet was decaying and releasing cold meltwater into the North Atlantic. This resulted in a steep thermal gradient between the North Atlantic Ocean and the Western Sahara, thereby enhancing the West African Monsoon (Renssen et al., 2003) — a situation promoted by cold upwelling in the Atlantic off the coast of North Africa at the end of cold phases such as the Younger Dryas $(12.9-11.7 \mathrm{ka})$ and the $8.2 \mathrm{ka}$ Event (Adkins et al., 2006). This produced a greater latitudinal temperature gradient between the tropics and the mid-latitudes over Africa, which effectively forced the West African Monsoon further north over the current Sahara region. Another condition thought to be favourable to this mechanism during the Late Pleistocene/early Holocene transition was the peak in solar radiation on the precessional orbital cycle at ca. $10.5 \mathrm{ka}$ (DeMenocal et al., 2008). This effectively intensified tropical heating and thus further amplifying the temperature contrasts between the North Atlantic Ocean and the Tropics causing the West African Monsoon to penetrate far into North Africa, and possibly into southern Europe (DeMenocal, 2008, DeMenocal et al., 2008). As noted earlier, DeMenocal (2008) found evidence for this mechanism occurring several times during the last cold stage, and it is likely that this fluctuation in the West African Monsoon also occurred during other cold stages.

In addition to providing an environmental proxy adjacent to the largest desert region on Earth, the glacial record of the High Atlas is also crucial for understanding the capacity of these mountain areas to support refugial populations of plant and animal species during Pleistocene cold stages. The mountainous peninsulas of southern Europe, as well as the mountains of North Africa, are thought to have hosted biotic refugia during Pleistocene cold stages (Hewitt, 2000). It is from these refugial centres that plants and animals colonised Europe during subsequent interglacials. The presence of glaciers in these proposed refugial centres during Pleistocene cold stages has important bearing on moisture supply as well as temperature, and large glaciers in the uplands would have limited the availability of 'temperate' refugial sites in topographically sheltered sites such as valley floors. Moreover, the strategic position of the High Atlas, in close proximity to routes of Palaeolithic human migration from Africa to Europe (Gibert et al., 2003, Finlayson et al., 2006), highlights the importance of understanding environmental conditions these mountains during Pleistocene cold stages.

\subsection{CONCLUSIONS}

The glacial history of the Atlas Mountains is important for several reasons. First, glaciers have shaped the high mountain landscape we see today and also affected geomorphological processes long after glacier retreat, such as through valley oversteepening, which caused subsequent major landslides and alluvial fans that are still active today. Second, evidence of past glaciers also tell us a great deal about past climate in the Atlas Mountains, which is of major significance given the strategic position of these mountains for understanding palaeo-atmospheric circulation, bordering 
the North Atlantic Ocean and the Mediterranean Sea. Third, the Atlas Mountains also border the Sahara-the largest modern desert region on Earth. Palaeoglaciers effectively act as palaeotemperature and palaeoprecipitation gauges and documenting their presence, size and altitude at different times during the Quaternary is of crucial importance for understanding palaeoenvironmental conditions in the Sahara region-especially moisture supply. Finally, the palaeoclimate record available from evidence of past glaciers in these mountains is important in providing an understanding of the environmental conditions endured by plant and animal species, including early humans, during Pleistocene cold stages. Recent progress towards establishing detailed geochronologies for the different glaciations will help constrain the palaeoclimatic and wider palaeoenvironmental interpretations that can be drawn from this record (Hughes and Woodward, 2008). Eventually, this data can be combined with other glacial records around the Mediterranean basin and used to help in our understanding of the climatological, geomorphological and biological evolution of southern Europe and North Africa.

\section{ACKNOWLEDGEMENTS}

This research was funded by a Thesiger-Oman International Fellowship to Philip Hughes from the Royal Geographical Society (with IBG) and NERC awards for cosmogenic isotope support (NERC CIAF Allocation Nos. 9038.1007 and 9070.1009).

\section{REFERENCES}

Adkins, J., DeMenocal, P., Eshel, G., 2006. The 'African Humid Period' and the record of marine upwelling from excess $230^{\mathrm{Th}}$ in Ocean Drilling Program Hole $658 \mathrm{C}$. Paleoceanography 21, PA4203. doi:10.1029/2005PA001200.

Awad, H., 1963. Some aspects of the geomorphology of Morocco related to the Quaternary climate. Geogr. J. 129, 129-139.

Balco, G., Stone, J.O., Lifton, N.A., Dunai, T.J., 2008. A complete and easily accessible means of calculating surface exposure ages or erosion rates from ${ }^{10} \mathrm{Be}$ and ${ }^{26} \mathrm{Al}$ measurements. Quat. Geochronol. 3, 174-195

Ballais, J.-L., 1983. Moraines et glaciers quaternaires des Aurès (Algerie). In: 108ème Congrès national de Sociétés savantes, Grenoble, 1983, Géographie, 291-303.

Barbier, A., Cailleux, A., 1950. Glaciare et périglaciaire dans le Djurdjura occidental (Algérie). CR Séances 'Académie Sci. Paris 231, 365-366, Juillet-Décembre 1950.

Beaudet, G., 1971. Le Quaternaire Marocain: édat des études. Rev. Géogr. Maroc 20, 3-56.

Büdel, J., 1952. Bericht über klimamorphologische und Eiszeitforschungen in Niederafrika. Erdkunde 6, 104-132.

Cacho, I., Grimalt, J.O., Pelejero, C., Canals, M., Sierro, F.J., Flores, J.A., et al., 1999. Dansgaard-Oeschger and Heinrich event imprints in Alboran Sea palaeotemperatures. Palaeoceanography 14, 698-705.

Celerier, J., Charton, A., 1923. Un lac d'origine glaciarire dans le Haut Atlas (Le lac d'Ifni). Hespéris 3, 501-513.
Chardon, M., Riser, J., 1981. Formes et processus géomorphologiques dans le Haut-Atlas marocain. Rev. Géogr. Alpine 69, 561-582.

Couvreur, G., 1966. Les formations périglaciares du Haut Atlas central Marocaine. Rev. Géogr. Maroc 10, 47-50.

Delannoy, H., 1971. Aspects du climat de la région de Marrakesh. Rev. Géogr. Maroc 20, 69-106.

DeMenocal, P.B., 2008. Africa on the edge. Nat. Geosci. 1, 650-651.

DeMenocal, P.B., Ortiz, J., Guilderson, T., Adkins, J., Sarnthein, M., Baker, L., et al., 2008. Abrupt onset and termination of the African Humid Period: rapid climate responses to gradual insolation forcing. Quatern. Sci. Rev. 19, 347-361.

Dresch, J., 1941. Recherches sur l'évolution du relief dans le Massif Central du Grand Atlas le Haouz et le Sous. Arrault et Cie, Maitres Imprimeurs, Tours. $653 \mathrm{pp}$.

Dresch, J., 1949. Sur des formations de remblaiement continental et la présence de formes glaciaires dans le Haut Atlas calcaire. CR Sommaire Séances Soc. Géol. Fr. 9-10, 169-171.

Dresch, J., Raynal, R., 1953. Les formes glaciaires et périglaciaires dans le Moyen Atlas. CR Sommaire Séances Soc. Géol. Fr. 11/12, 195-197.

Dunai, T., 2001. Influence of secular variation of the magnetic field on production rates of in situ produced cosmogenic nuclides. Earth Planet. Sci. Lett. 193, 197-212.

Finlayson, C., et al., 2006. Late survival of Neanderthals at the southernmost extreme of Europe. Nature 443, 850-853.

Flint, R.F., 1971. Glacial and Quaternary Geology. Wiley, New York, $892 \mathrm{pp}$.

Florineth, D., Schlüchter, C., 2000. Alpine evidence for atmospheric circulation patterns in Europe during the last glacial maximum. Quatern. Res. 54, 295-308.

Ghienne, J.-F., 2003. Late Ordovician sedimentary environments, glacial cycles, and post-glacial transgression in the Taoudeni Basin, West Africa. Palaeogeogr. Paleoclimatol. Palaeoecol. 189, 117-145.

Gibert, J., Gibert, L., Iglesias, A., 2003. The Gibraltar Strait: a Pleistocene door of Europe? Hum. Evol. 18, 147-160.

González Trueba, J.J., Martín Moreno, R., Martínez de Pisón, E., Serrano, E., 2008. 'Little Ice Age' glaciation and current glaciers in the Iberian Peninsula. Holocene 18, 551-568.

Hewitt, G.M., 2000. The genetic legacy of the Quaternary ice ages. Nature 405, 907-913.

Heybrock, W., 1953. Eiszeitliche Gletscherspuren und heutige Schneeverhältnisse im Zentralgebiet des Hohen Atlas. Z. für Gletscherk. Glazialgeol. 2, 317-321.

Hughes, P.D., 2010. Little Ice Age glaciers in Balkans: low altitude glaciation enabled by cooler temperatures and local topoclimatic controls. Earth Surf. Process. Land. 35, 229-441.

Hughes, P.D., Woodward, J.C., 2008. Timing of glaciation in the Mediterranean mountains during the last cold stage. J. Quatern. Sci. 23, 575-588.

Hughes, P.D., Gibbard, P.L., Woodward, J.C., 2004. Quaternary glaciation in the Atlas Mountains, North Africa. In: Ehlers, J., Gibbard, P.L. (Eds.), Quaternary Glaciation-Extent and Chronology. Volume 3: Asia, Latin America, Africa, Australia, Antarctica. Elsevier, Amsterdam, pp. 255-260.

Hughes, P.D., Woodward, J.C., Gibbard, P.L., 2006. Glacial history of the Mediterranean mountains. Prog. Phys. Geogr. 30, 334-364.

Hughes, P.D., Gibbard, P.L., Woodward, J.C., 2007. Geological controls on Pleistocene glaciation and cirque form in Greece. Geomorphology $88,242-253$. 
Joly, F., 2002. Hommage à René Raynal (1914-2002). Géomorphologie 8, 269-271.

Mark, B.G., Osmaston, H.A., 2008. Quaternary glaciation in Africa: key chronologies and climatic implications. J. Quatern. Sci. 23, 589-608.

Mensching, H., 1953. Morphologische Studien im Hohen Atlas von Marokko. Würzburger Geographische Arbeiten H.1, 104 pp.

Mensching, H., 1960. Bericht und Gedanken zur Tagung der Kommission für Periglazialforschung in der IGU in Marokko vom 19. bis 31. Oktober, 1959. Z. Geomorphol. N.F. 4, 159-170.

Messerli, B., 1967. Die eiszeitliche und die gegenwartige Vertgletscherung im Mittelemeerraum. Geogr. Helv. 22, 105-228.

Osmaston, H.A., Harrison, S.P., 2005. The late Quaternary glaciation of Africa: a regional synthesis. Quatern. Int. 138, 32-54.

Pique, A., 2001. Geology of Northwest Africa. Beiträge Zur Regionalen Geologie Der Erde, Band 29. Gebrüder Borntraeger.

Pouclet, A., Aarab, A., Fekkak, A., Benharraf, M., 2007. Geodynamic evolution of the northwestern Paleo-Gondwanan margin in the Morocco Atlas at the PreCambrian-Cambrian boundary. Geol. Soc. Am. Spec. Publ. 423, 27-60.

Raynal, R., 1952. Quelques examples de l'action du froid et le neige sur les formes du relief au Maroc. Notes Marocaines 2, 14-18.

Raynal, R., Dresch, J., Joly, F., 1956. Deux exemples régionaux de glaciation quaternaire au Maroc: Haut Atlas Oriental, Moyen Atlas Septentrional. In: IV Congrès INQUA, Rome-Pisa, pp. 108-117.
Renssen, H., Brovkin, V., Fichefet, T., Goosse, H., 2003. Holocene climate instability during the termination of the African Humid Period. Geophys. Res. Lett. 30 (4), 1184. doi:10.1029/2002GL016636, 2003.

Rhanem, M., 2009. L'Alfa (Stipa tenacissima L.) dans las plaine de Midelt (haut bassin versant de la Moulouya, Maroc)—elements de climatologie. Physio Géo Géogr. Phys. Environ. 3, 1-20.

Robinson, D.A., Williams, R.B.G., 1992. Sandstone weathering in the High Atlas, Morocco. Z. Geomorphol. 36, 413-429.

Ruddimann, W.F., McIntyre, A., 1981. The North Atlantic Ocean during the last deglaciation. Palaeogeogr. Palaeoclimatol. Palaeoecol. 35, 145-214.

Tihay, J.-P., 1972. Modelés cryonival et glaciaire dans la haute montagne Algérienne: l'exemple de la chaîne du Djurdura (Grande Kabylie). Rev. Géogr. Montréal 26, 447-463.

Tihay, J.-P., 1973. Note sur quelques paléoformes $<$ periglaciaires $>$ observées en Algérie orientale. Mediterranée 13 (2), 37-47.

Vita-Finzi, C., 1969. The Mediterranenan Valleys. Geological Changes in Historical Times. Cambridge University Press, London, 140 pp.

Wiche, K., 1953. Klimamorphologische und talgeschichtliche Studien im M'Goungebiet. Mitt. Der Geographischen Ges. Wien 95, 4-41.

Williams, M., Dunkerley, D., De Decker, P., Kershaw, P., Chappell, J., 1998. Quaternary Environments, second ed. Arnold, London, 329 pp.

World Meteorological Organisation, 1998. 1961-1990 Global Climate Normals. National Climatic Data Center, Asheville, NC, US Electronic resource. (CD-ROM). 